
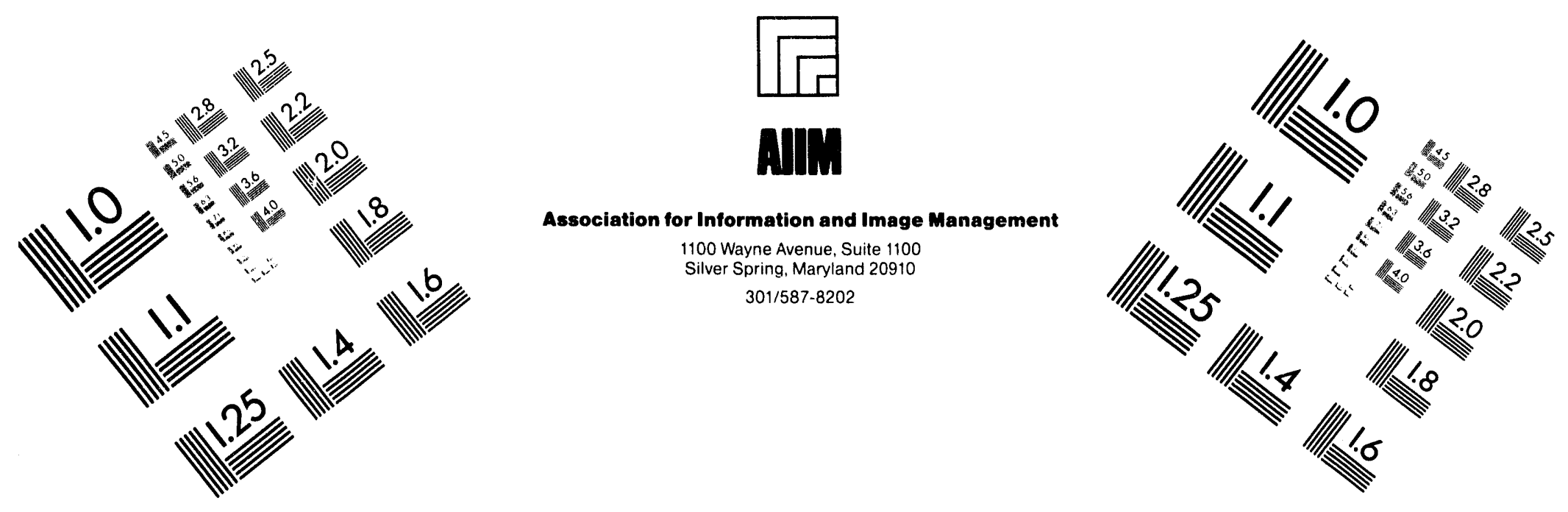

\title{
Centimeter
}

${ }_{1}$ Inches
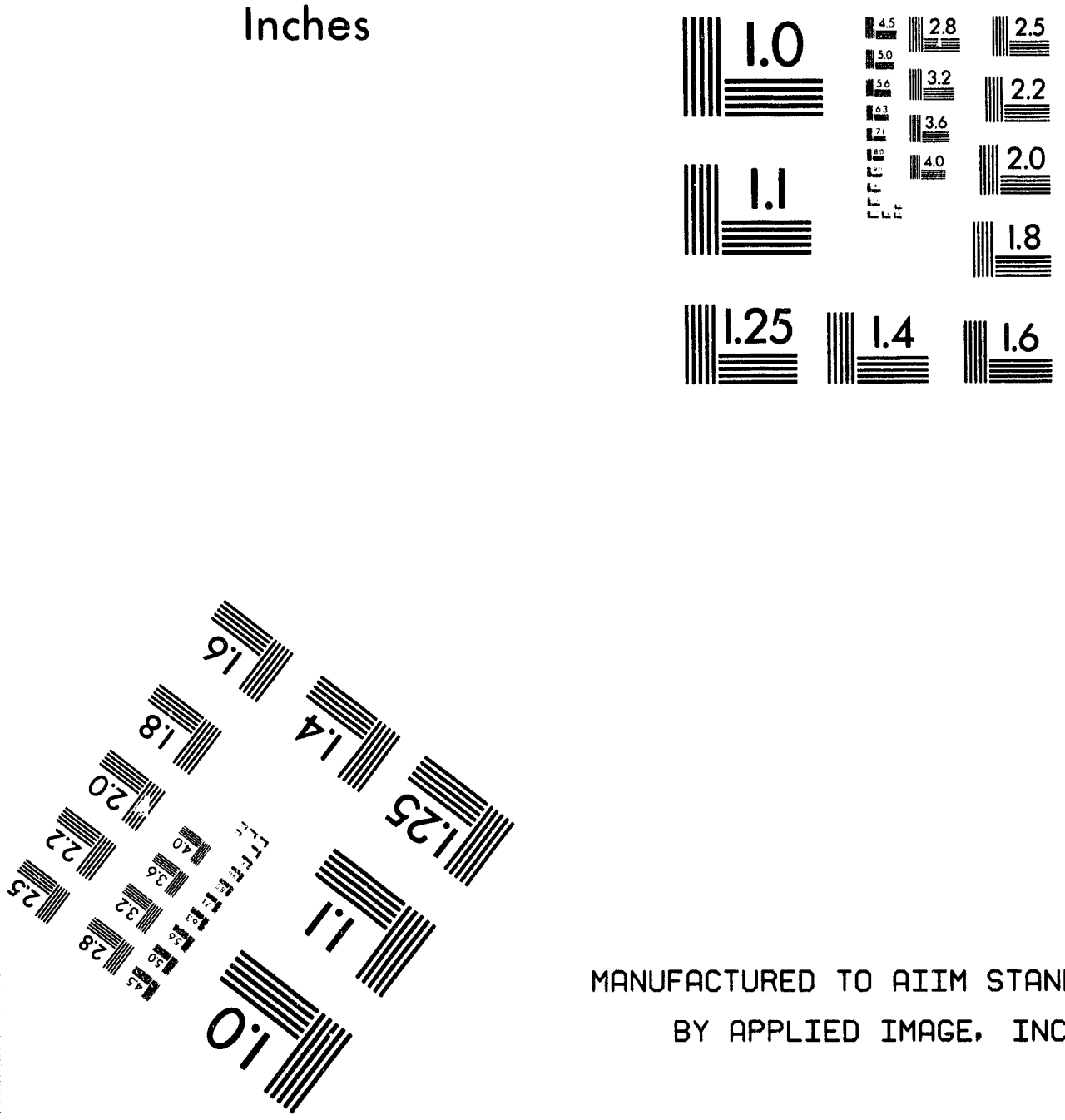

MANUFACTURED TO AIIM STANDARDS

BY APPLIED IMAGE, INC.

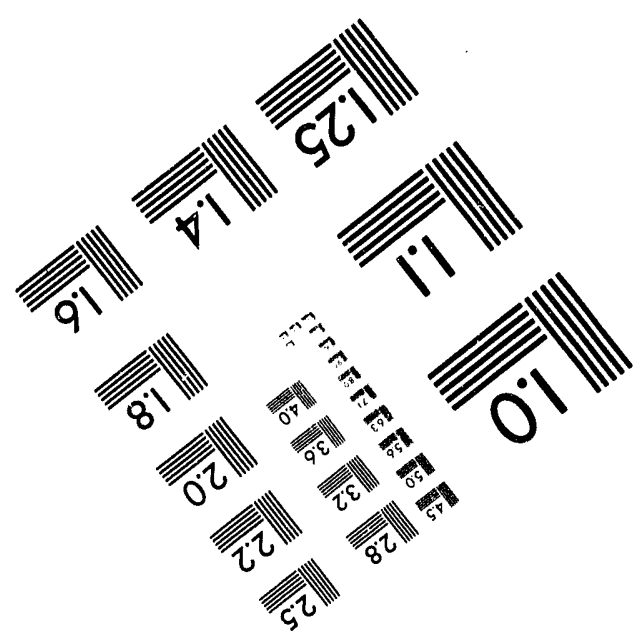



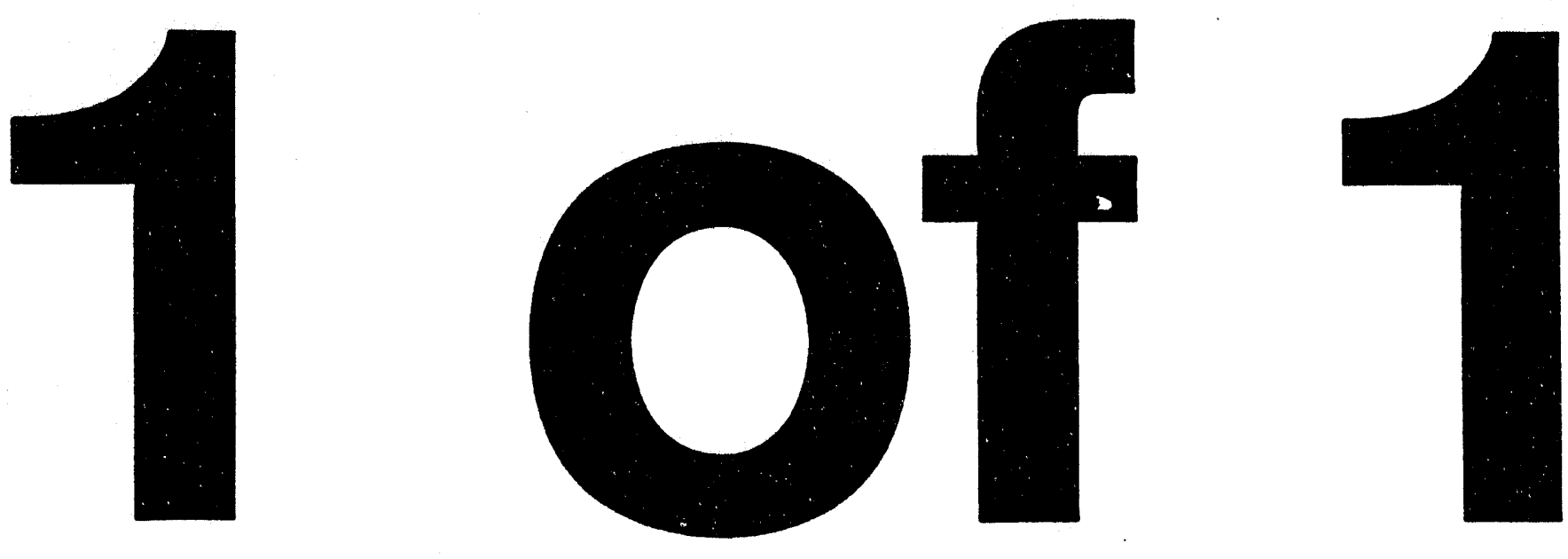


\section{TECHNICAL REVIEW OF WSRC-TR-93-614 CRITICALITY SAFETY EVALUATION FOR DISASSEMBLY BASIN SAND FILTER (U)}

by

Reed, R. L.

Westinghouse Savannah River Company

Savannah River Site

Alken, South Carolina 29808

DOE Contract No. DE-AC09-89SR 18035

This paper was prepared in connection with work done under the above contract number with the U. S.

Department of Energy. By acceptance of this paper, the publisher and/or recipient acknowledges the U.S. Government's right to retain a nonexclusive, royalty-free license in and to any copyright covering this paper, along with the right to reproduce and to authorize others to reproduce all or part of the copyrighted paper. 


\section{DISCLAIMER}

This report was prepared as an account of work sponsored by an agency of the United States Government. Neither the United States Government nor any agency thereof, nor any of their employees, makes any warranty, express or implied, or assumes any legal liability or responsibility for the accuracy, completeness, or usefulness of any information, apparatus, product, or process disclosed, or represents that its use would not infringe privately owned rights. Reference herein to any specific commercial product. process, or service by trade name, trademark, manufacturer, or otherwise does not necessarily constitute or imply its endorsement, recommendation, or favoring by the United States Government or any ageacy thereof. The views and opinions of authors expressed berein do not necessarily state or reflect those of the United States Governmeat or any agency thereof.

This report has been reproduced directly from the best available copy.

Available to DOE and DOE contractors from the Office of Scientific and Technical Information. P. O. Box 62, Oak Ridge, TN 37831: prices available from (615) $576-8401$.

Available to the public from the National Technical Information Service. U. S. Department of Commerce, 5285 Port Royal Rd., Spriagfield. VA 22161 
April 27, 1994

KEYWORDS:

UNCLASSIFIED

Reactor

Technical

DOES NOT CONTAIN UNCLASSIFIED

Disassembly

ADC 8 CONTROLLED NUCLEAR INFORMATION

Criticality

OFFICIAL

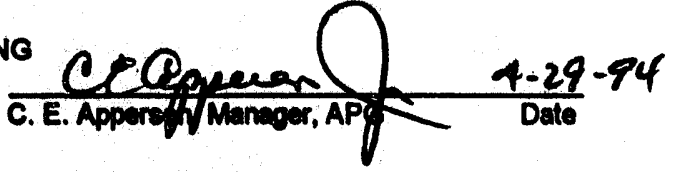

RETENTION:

PERMANENT

\section{TECHNICAL REVIEW OF WSRC-TR-93-614}

Criticality Safety Evaluation for Disassembly Basin Sand Filter (U)

Author

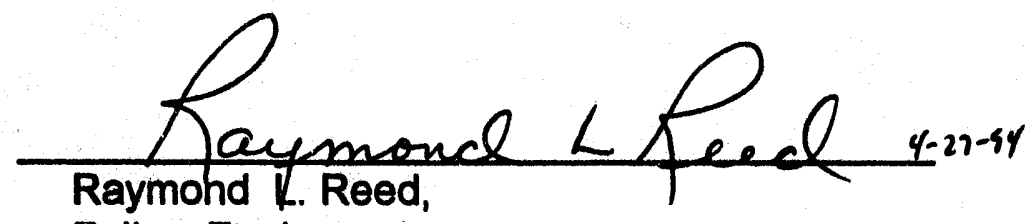

Fellow Engineer

APPROVAL

Manager

Applied Physics Group (APG)

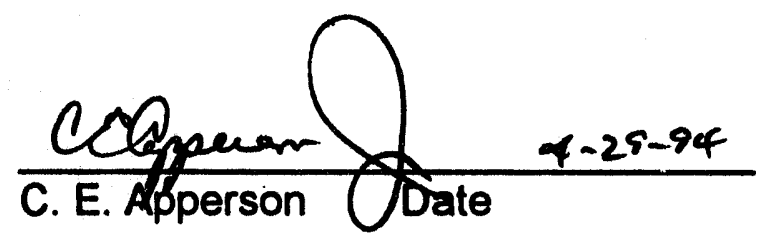

Distribution:

F. Beranek,

M. R. Buckner,

C. E. Apperson,

J. F. Mincey,

M. A. Rosser,

R. L. Reed,
773-A

773-42A

773-24A

773-22A

$705-\mathrm{K}$

773-42A
E. F. Trumble,

T. G. Williamson,

R. L. Webb,

R. W. Rathbun,

Technical Information Management, 703-43A

APG Files,
786-1A

773-42A

786-1A

786-1A

773-24A 


\section{INTRODUCTION}

The study documented in WSRC-TR-93-614 (Reference 1) performed an evaluation of the criticality potential associated with the Disassembly Basin Sand Filter for K and L Areas. The document reviewed incorporated results of calculations documented in the engineering calculation N-CLC-K-00151 (Reference 2).

Analyses of the contents of disassembly basin sludge has indicated that the sludge contains fissile material in excess of subcritical mass limits as specified in ANSI/ANS standards (References 3 and 4). Previous studies (listed in the reference section of the reviewed document) had determined that the fissile material can not collect into a critical configuration in the basin. Since the sand filter is intended to remove suspended particles from the basin water and could serve as a mechanism to collect the fissile material into a critical configuration, the study examined conditions under which criticality could occur in the sand filter. The study shows that criticality is not considered possible in the sand filter.

This review emphasized the technical accuracy and presentation of the evaluation. The evaluation was also examined for the elements required for NCSEs by Reference 5. The review was performed in accordance with the NRTSC technical review requirements and procedures (References 6 and 7) (See Appendix A)and the E7 Manual technical review requirements (References 8 and 9). The technical review (per the E7 manual) of the engineering calculation (N-CLC-K-0151) was previously performed by this reviewer.

\section{DISCUSSION}

WSRC-TR-93-614 presents an evaluation, based on engineering calculations documented in NCLC-K-00151, in the format specified by WSRC-IM-93-13. The evaluation focused on determining the geometry configurations under which the fissile material in the basin, having all been transferred to the cand filter, would be critical. Very conservative assumptions were used, including:

- Treating the fissile material as fissile material only, without accounting for the presence of ${ }^{238} \mathrm{U}$ and iron in the sludge. Those elements act as neutron posions.

- All fissile material in the basin is transferred to the sand filter.

- Best estimate and conservative $(2.6 \times \mathrm{BE})$ values of fissile material content.

The review consisted of

- a careful reading of the draft document and the final version,

- verification that the results of the engineering calculation, N-CLC-K-00151, are accurately reflected by the evaluation,

- suggestions to the author of additional discussion items and material to be included from the engineering calculation to make the document more complete, and

- editorial suggestions to the author

No additional calculations were performed as part of this review. 


\section{NCSE Required Elements}

WSRC-IM-93-13 (Reference 4) specifies a set of required elements for an NCSE. That set of elements corresponds to the elements required by DOE Orders and Standards, such as DOE Order 5480.24 and LOE-STD-3007-93. The elements are listed below, along with an assessment of how they are implemented in the NCSE.
Introduction
The purpose and scope of the study were indicated in the Introduction and Summary sections.
Description
A brief description of the sand filter and its operation was provided in the Description section. References for sand filter layout and construction were indicated.

Requirements
Documentation
Methodology
Discussion of
Contingencies
Evaluation of
Results
Design Features
(Active and
Passive) and
Administratively
Controlled Limits
\& Requirements

\section{A statement of requirements documentation was provided in the Requirements} Documentation section.
The methodology used was indicated and discussed in the Methodology section.
Since the evaluation showed criticality is not possible, the Discussion of Contingencies section indicated no need for such discussion.
The calculational results from N-CLC-K-00151 are discussed in the Evaluation and Results section. The results are also briefly discussed in the Summary section and the Conclusions section and are interpreted as no possibility of criticality.
The section is provided, although noting, since there is no possibility of criticality, there are no administrative limits required. Discussion of aspects of sand filter operation is provided as reinforcement of the basis of the "no criticality possible" conclusion
Summary and
Conclusion
References
Appendices
The Summary section and the Conclusions section discusses the results presented in the Evaluation and Results section, indicating that criticality is not a concern for the sand filter.
Appropriate references are listed.
No appendices were required

The elements required by WSRC-IM-93-13 are satisfied.

\section{SUMMARY AND CONCLUSIONS}

The evaluation is excellently presented and well supports the conclusion that criticality is not a concern in the sand filter, unless significant changes are made in Disassembly Sand Filter operations. 


\section{REFERENCES}

1. M. A. Rosser, Criticality Safety Evatuation for Disassembly Basin Sand Filter (U), WSRC-TR-93-614, May 1994

2. M. A. Rosser, "Calculations for Sand Filter Criticality Safety Evaluation", N-CLC-K-00151, Revision 0, March 1994

3. "American National Standard for Nuclear Criticality Safety in Operations with Fissionable Materials Outside Reactors", ANS-8.1-1983, October 7, 1983

4. "American National Standard for Nuclear Criticality Control of Special Actinide Elements", ANS-8.15-1981, November 9, 1981

5. WSRC-IM-93-13, Rev.1, Westinghouse Savannah River Company Nuclear Criticality Safety Manual (U)

6. MANUAL 1Q34, NRTSC QUALTTY ASSURANCE MANUAL, January 1991

7. NRTSC QA Procedure QAP II-14, "TECHNICAL REVIEW", August, 1991

8. Procedure Manual E7, Revision 5, Conduct of Engineering and Technical Support (U)

9. Procedure 2.40 (E7 Manual), Revision 0, "Design Verification and Checking" (U) 
OSR 24-K7

\section{ATTACHMENT A NRTSC REVIEW SHEET}

TASK TITLE NCSE FOR DISASSEMBLY SAND FILTER

TASK NUMBER_ N/A

ITEM REVIEWED WSRC-TR-93-614

(Attach additional pages as necessary; marked-up pages are acceptable.)

\section{Areas reviewed (identify clearly each area reviewed).}

Logic, clarity, accuracy, and applicability of presentation

Consistency of data values presented with engineering calulation N-CLC-K-00151

Adequacy of methodology chosen

Consistency with WSRC-IM-93-13

\section{Approaches used to perform the review.}

Read the document carefully.

Evaluated adequacy of methodology used (hand calculations and KENO-V.a scoping calculations.

(This reviewer performed the E7 review of the engineering calculation, N-CLC-K-00151)

Checked for consistency with N-CLC-K-00151

Discussed editorial suggestions with author

Confirmed implementation of suggested improvements in final version of document

3. Questions, comments to be resolved.

None:

$\mathrm{X}$ I agree with the technical content I disagree with the technical content.

X I accept the conclusions and recommendations

I do not accept the conclusions and recommendations for the following reasons:

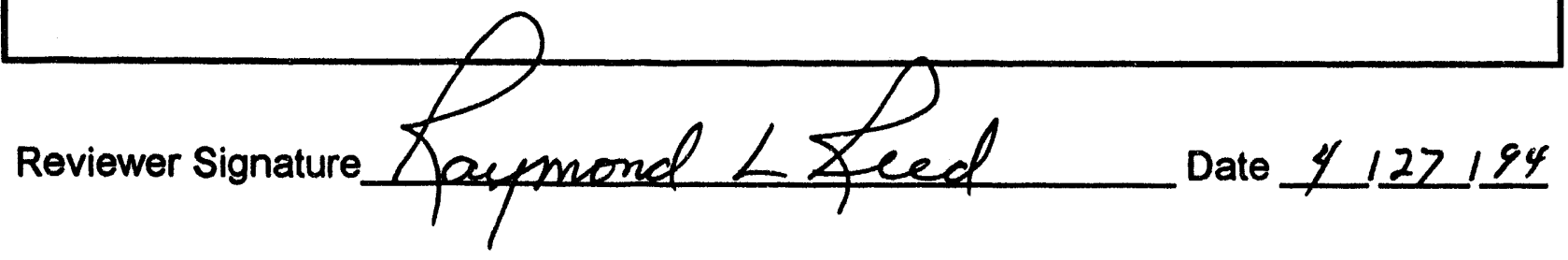




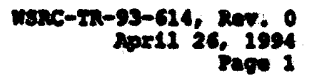

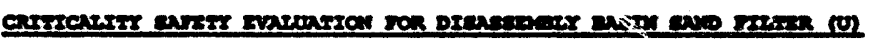
Dimcooceroin

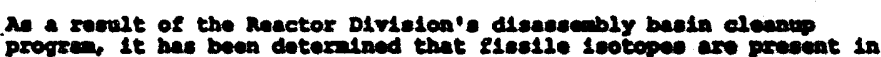
progren, it hac

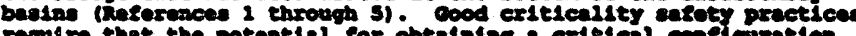
1 the

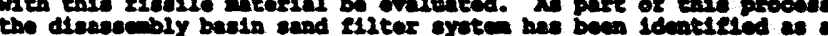

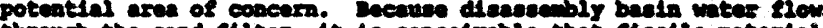

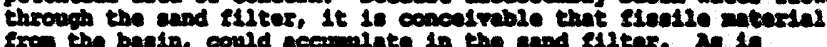

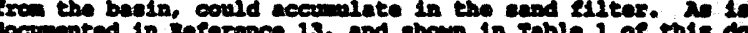

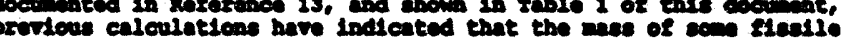

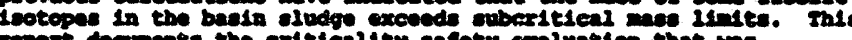
coport doewante the exlticality safoty graluation that mo

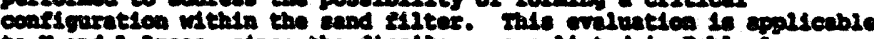

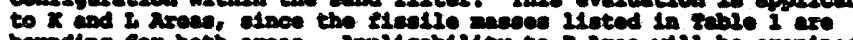

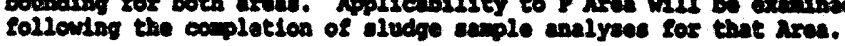

mancing

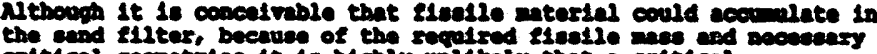

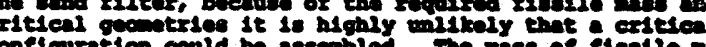

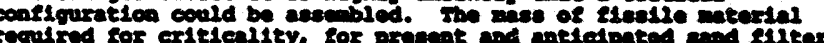

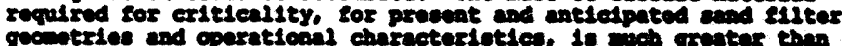

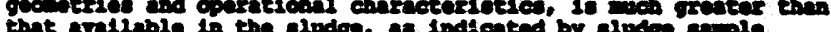

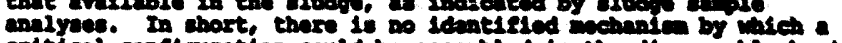

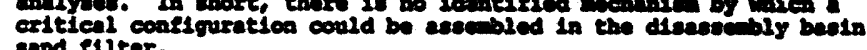

\section{Drecouszon}

Dosoriptica - ensd rultar operntica

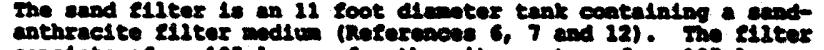

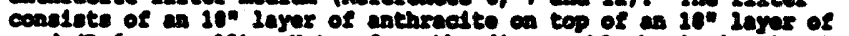

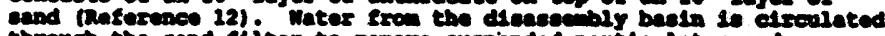

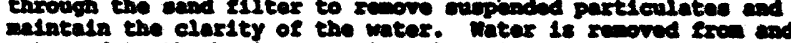

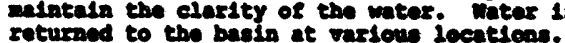

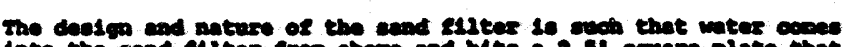
the and uite 2 s.

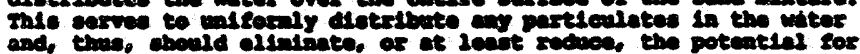

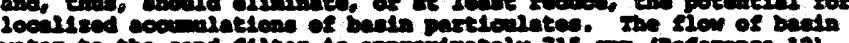

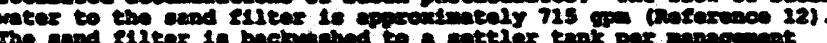

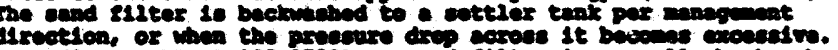

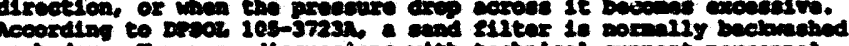

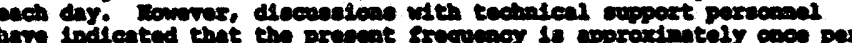

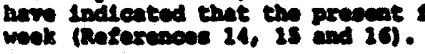

It 1e expeted that on type of and elitar w112 bo pot late

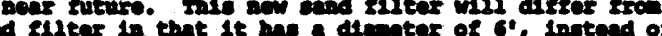
11\%. asd 1 in wh

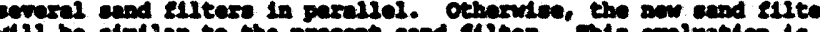
aplicabie to tho chellos tend siltet.

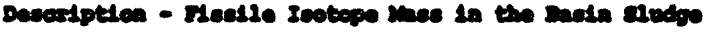

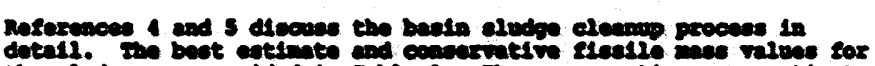

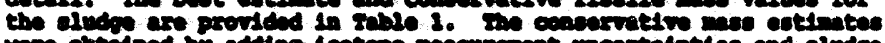

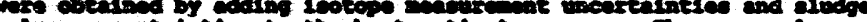

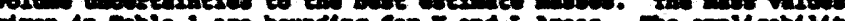

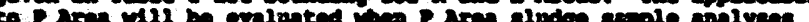
beocies aviliable.

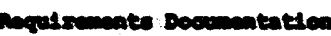

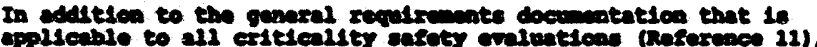

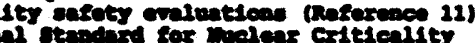

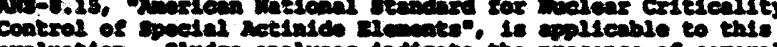

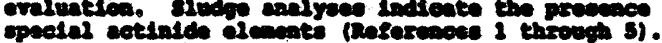

rotedodolose

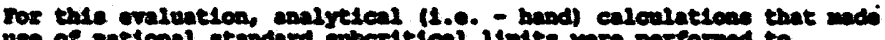

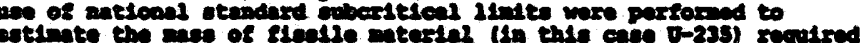

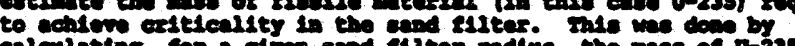

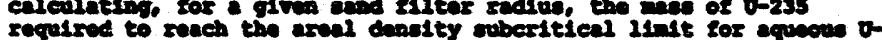




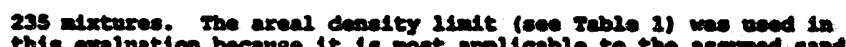

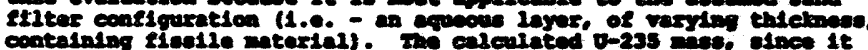

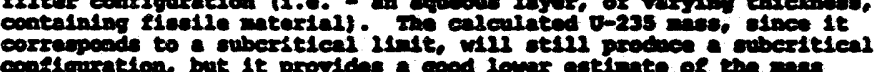

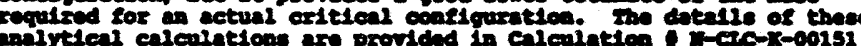

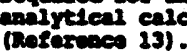

In ordar to provide independent moport tor the above anelyeteal

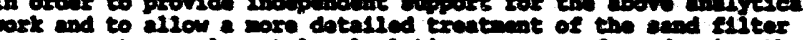

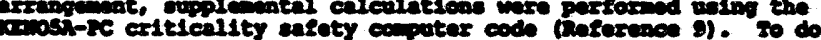

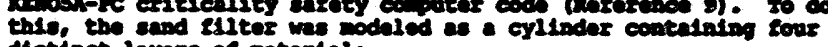
distinct layers of anteriei

1. 12" matar layax

3. 19" anthracite

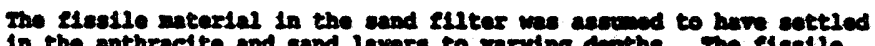

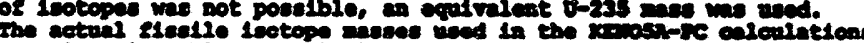

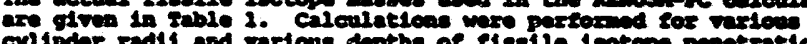

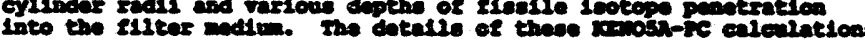

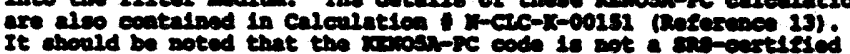

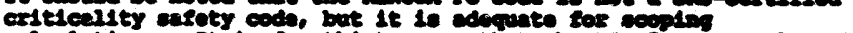

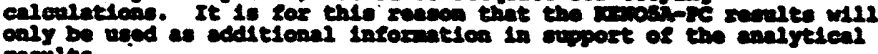

sveluetican and noculte

The repults of the analytlan calcelattoas aro proptend in zable 2. silter cace 10 a

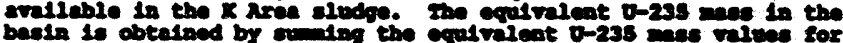

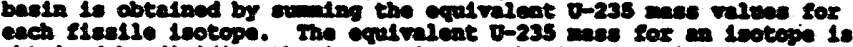

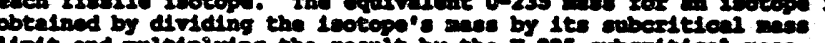

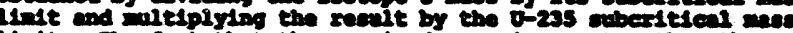

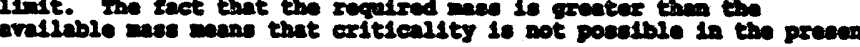

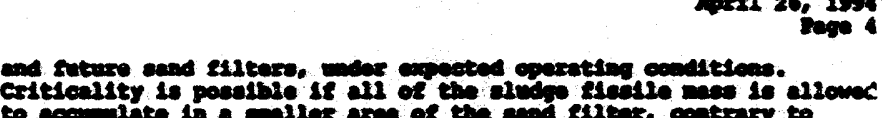

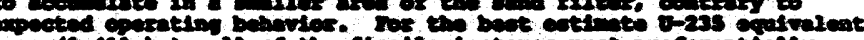

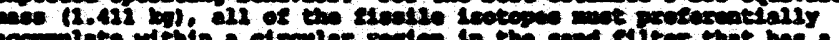

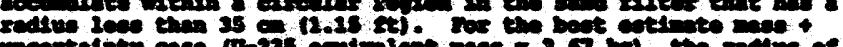

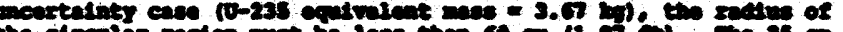

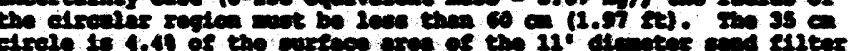

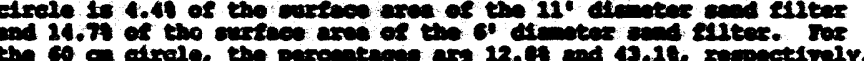

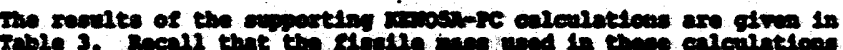
to the

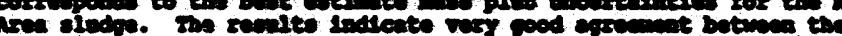

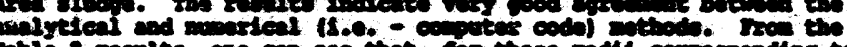

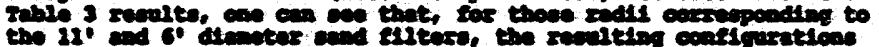

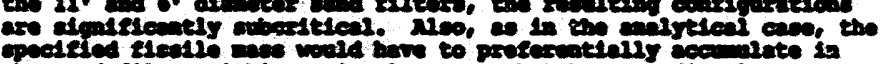

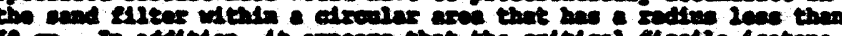

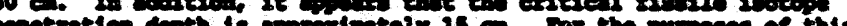

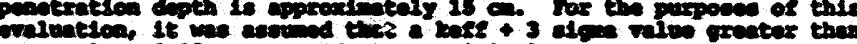
of equal to 0.95 correcpeade to : exteleal oroten.

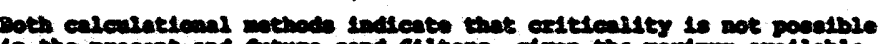

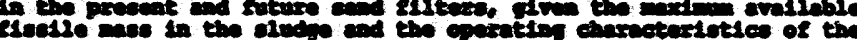

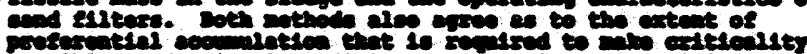

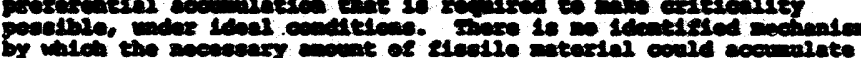

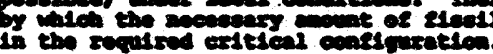

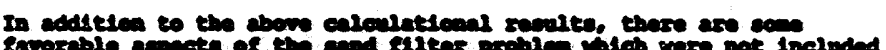

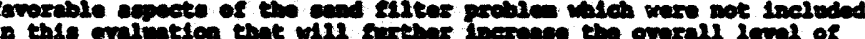

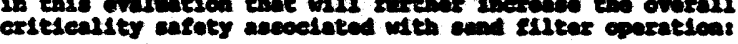

- rase crelvation did not conelder tropo matortals in the alvepe

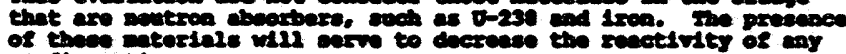

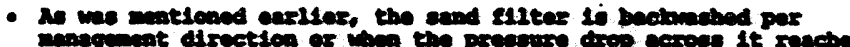

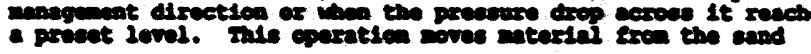


ATTACHMENT B

WSRC-TR-93-614 (Text and Tables)
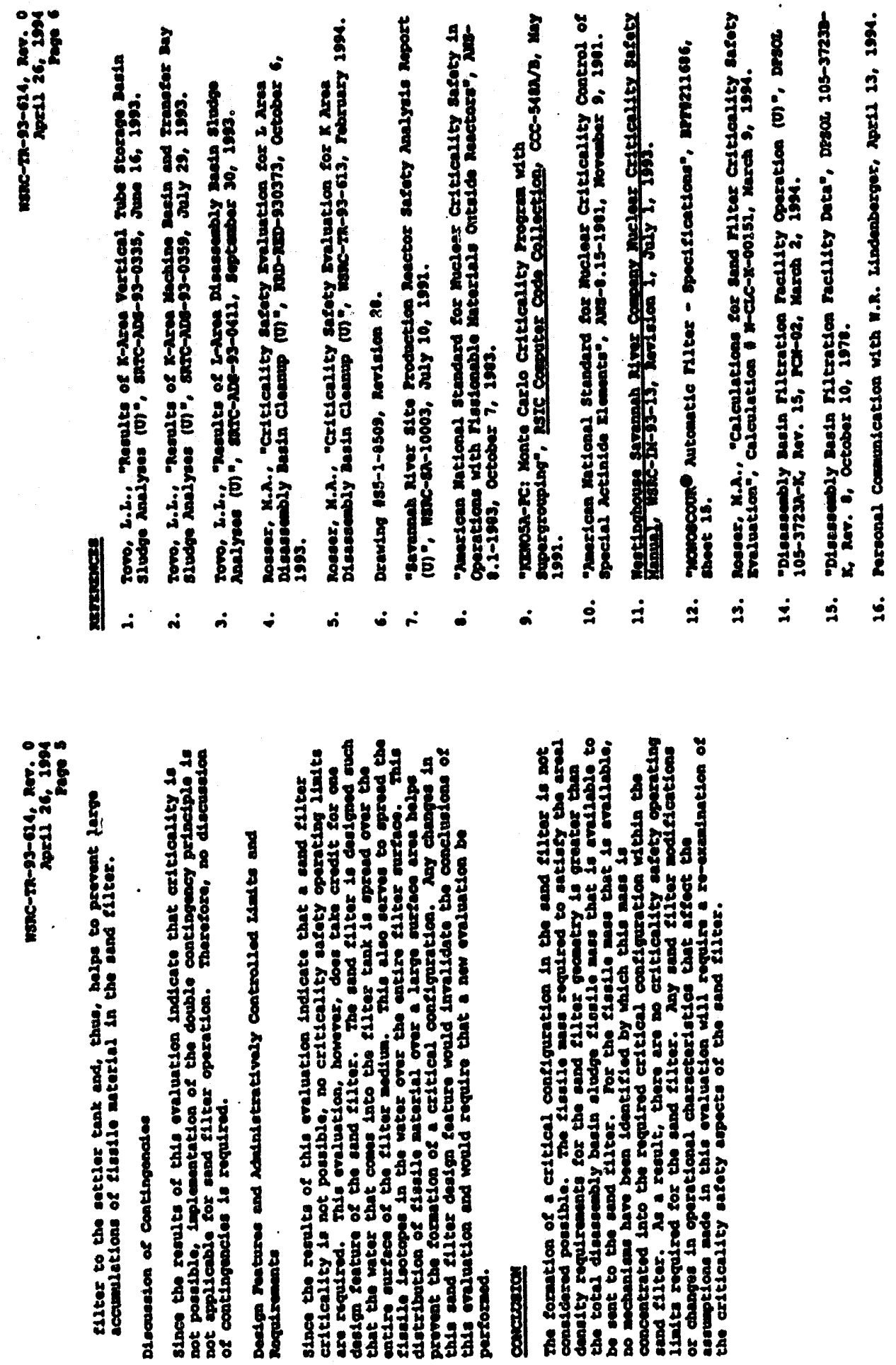


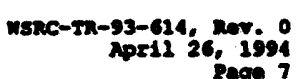

zasur 1

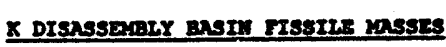

\begin{tabular}{|c|c|c|c|c|c|}
\hline Feoteme & 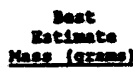 & 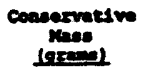 & 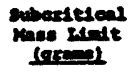 & 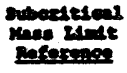 & 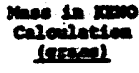 \\
\hline $0-233$ & 0.7 & 1.8 & 500 & $200-0.2$ & 2.0 \\
\hline 0 -295s & 906.9 & 2357.8 & 700 & $200-6.1$ & 2659.2 \\
\hline $20-23 s$ & 191.3 & 197.4 & 430 & $x=3-6.2$ & 497.4 \\
\hline $80-242$ & 3.0 & 9.9 & 200 & $2 x=0.15$ & 9.9 \\
\hline $20-212 m$ & 3.3 & 0.6 & 23 & $20=0-0.15$ & • \\
\hline$a-243$ & 1.9 & 4.9 & 90 & Am-1.15 & - \\
\hline
\end{tabular}

- 0-235 mase in the rono celculattons mas 1 nexceased by an apount

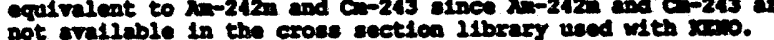
nonres:

1. Suberitical areal density 11 ant for $0-235=0.40 \mathrm{~g} / \mathrm{cm}^{2}$ (anes-

2. Conservative mess 18 based on an assumed 30 uncortalnty in bealn gepple analyaes and a doubling of sludge depth eetinate
maltipilcative ractor $=2.6$ ).

3. The mase values in the above rable are bounding for $\mathrm{K}$ and 2

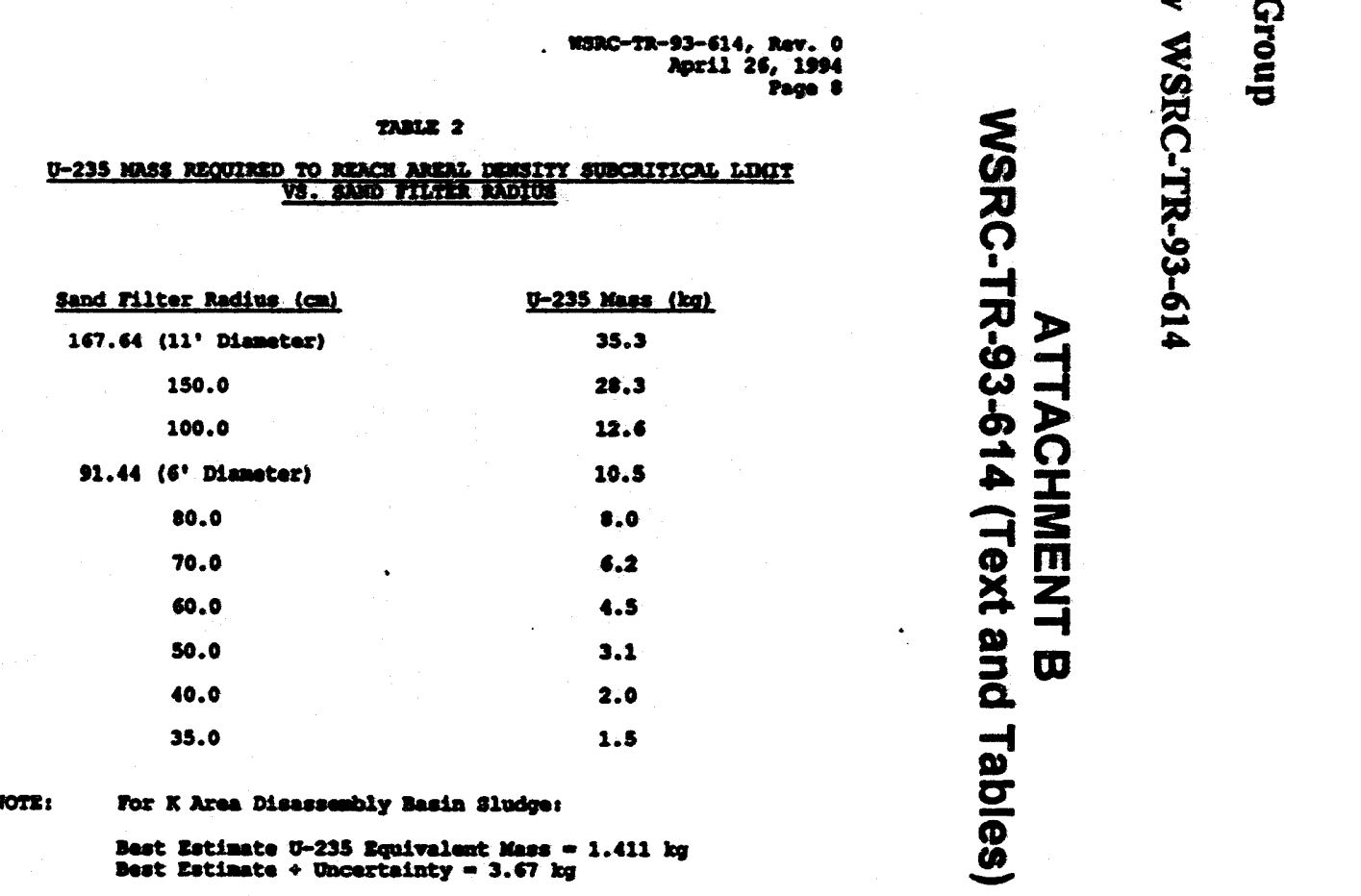

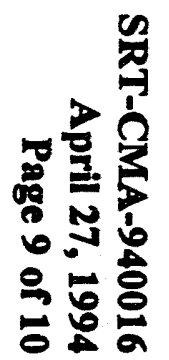


nsRC-7n-93-614, 2007

Apri2 26,1994

mabrx 3

moosh-8C Resurts

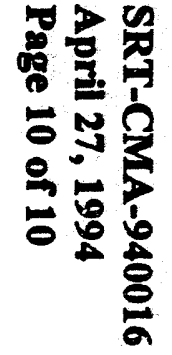

\begin{tabular}{|c|c|c|c|c|}
\hline $\begin{array}{l}\text { Cylinder } \\
\text { Redius (a) }\end{array}$ & $\begin{array}{l}\text { Tiastie } \\
\text { Leyer (ci) }\end{array}$ & keft & seonen & $\begin{array}{l}\text { kotz + } \\
\text { sigen }\end{array}$ \\
\hline 167.64 & 5.0 & 0.31198 & 0.00616 & 0.33034 \\
\hline 167.44 & 25.0 & 0.21867 & 0.00194 & 0.22450 \\
\hline 167.64 & 70.72 & 0.11087 & 0.00064 & 0.11277 \\
\hline 91.44 & 5.0 & 0.63677 & 0.02136 & 0.67083 \\
\hline 92.44 & 25.0 & 0.37012 & 0.00301 & 0.50316 \\
\hline 91.44 & 70.72 & 0.32678 & 0.00145 & 0.33112 \\
\hline 60.0 & 5.0 & 0.81231 & 0.01291 & 0.25103 \\
\hline 60.0 & 15.0 & 0.95132 & 0.01147 & 0.90374 \\
\hline 60.0 & 25.0 & $\% 0.91979$ & 0.00723 & 0.94147 \\
\hline 60.0 & 35.0 & 0.03733 & 0.00782 & 0.86080 \\
\hline 60.0 & 70.72 & 0.59799 & 0.00470 & 0.61233 \\
\hline 50.0 & 15.0 & 1.06155 & 0.01180 & 1.09693 \\
\hline 10.0 & 15.0 & 1.17012 & 0.01390 & 1.21181 \\
\hline
\end{tabular}

- compare to $x_{\text {erit }}=0.95$ to dotornine crltieal configurations.
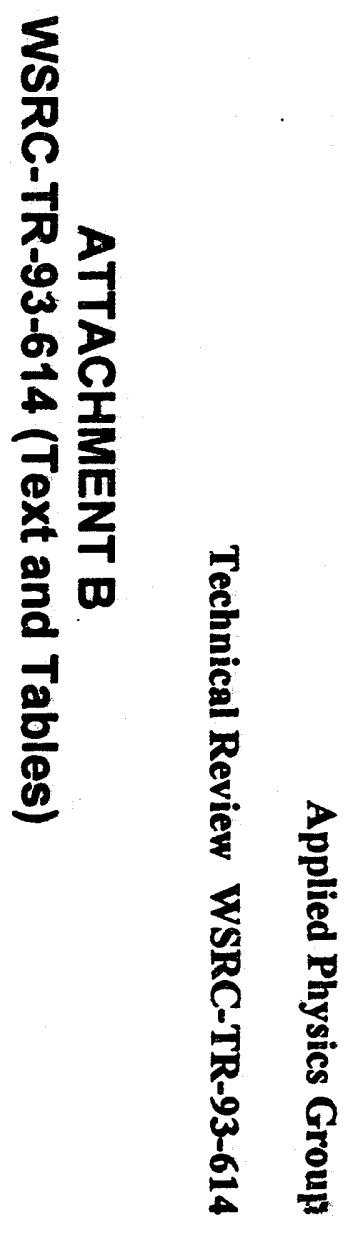

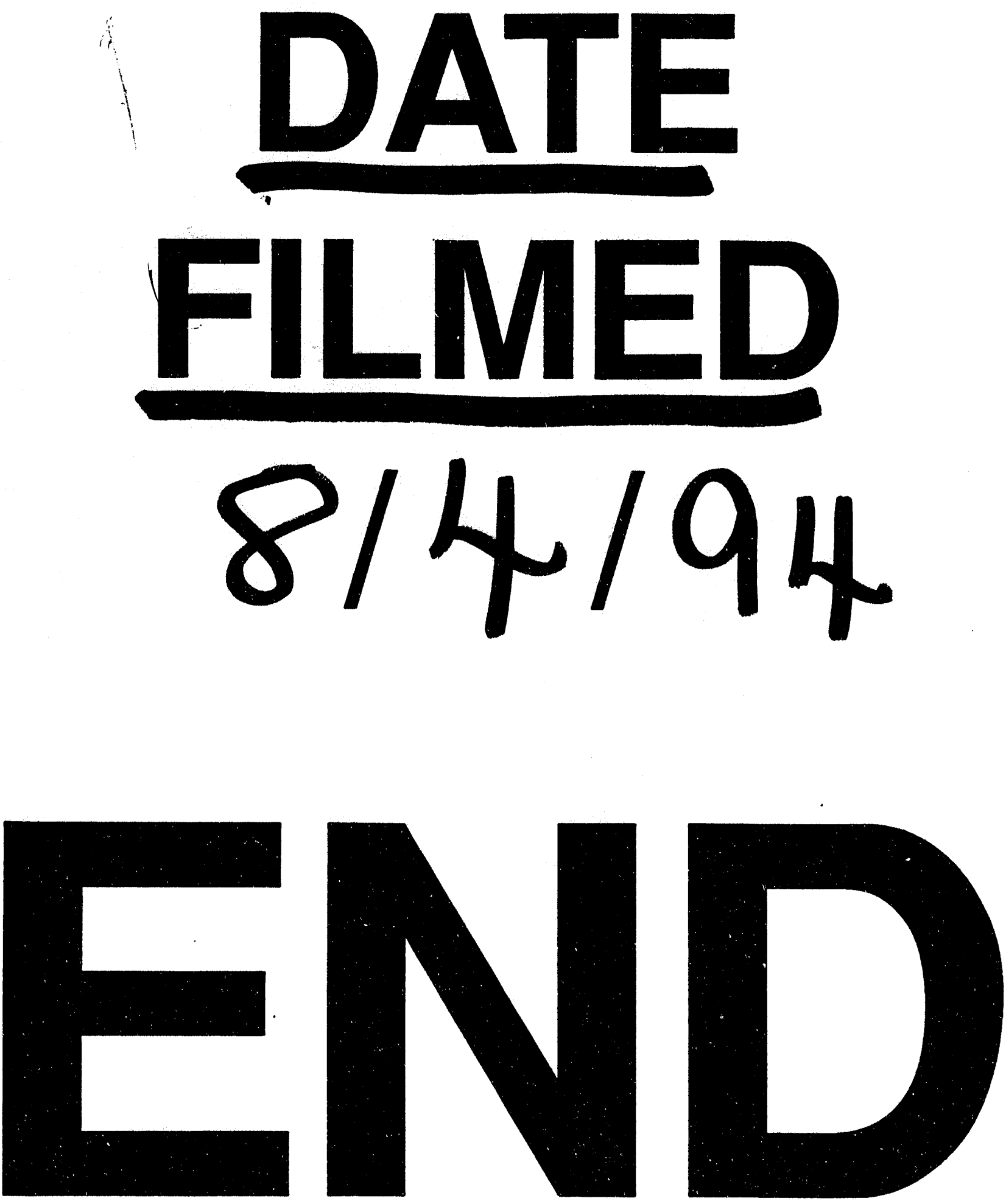
